\title{
The Impact of Consolidation and Modernisation on Banking Scale and Scope Economies
}

\author{
Ali Awdeh ${ }^{1}$, Chawki El-Moussawi ${ }^{1} \&$ Wafaa Nasser ${ }^{1}$ \\ ${ }^{1}$ Faculty of Economics and Business Administration, Lebanese University, Hadath, Lebanon \\ Correspondence: Ali Awdeh, Faculty of Economics and Business Administration, Lebanese University, Hadath, \\ Lebanon. Tel: 961-3-953-827. E-mail: ali.awdeh@ul.edu.lb
}

Received: February 11, 2016

Accepted: March 2, 2016

Online Published: April 25, 2016

doi:10.5539/ijef.v8n5p169

URL: http://dx.doi.org/10.5539/ijef.v8n5p169

\begin{abstract}
Lebanese banks recorded an enormous increase in size, customers' base, and products variety over the past two decades, which suggests the development of economies of scale and scope in the Lebanese banking sector. This study aims at testing the presence of these economies of scale and scope in the Lebanese banking sector, particularly over the period 2000-2013. The estimation of a translogarithmic cost function by the maximum likelihood method shows that the Lebanese banks are - in general - characterised by the existence of increasing economies of scale. The analysis of economies of scope also reveals a complementarity between different outputs. Finally, the analysis of price elasticities of demand for production factors shows an important substitutability between labour and physical capital.
\end{abstract}

Keywords: economies of scale, economies of scope, elasticity of substitution, translog function

\section{Introduction}

The Lebanese banking sector witnessed substantial changes over the past twenty-five years. One of the most important changes has been the significant decline in the number of commercial banks operating in the Lebanese markets, coupled with a large increase in the size of those banks.

A major reason behind this phenomenon was the merger and acquisition operations that took place particularly between 1993 and 2002. This wave of bank consolidations was triggered and encouraged by the banking supervisory and regulatory authorities that worked on passing the law of banking merger in January 1993. This law aimed at facilitating bank mergers and acquisitions and offered several incentives to merged banks (see Awdeh \& El-Moussawi, 2011). In addition to the consolidations among Lebanese banks, several foreign banks exited the Lebanese market, mainly after (and due to) the 2007 international financial crisis, where several international banks decided to terminate their operations in many foreign markets.

Consequently, the number of commercial banks operating in Lebanon declined from 72 banks in 1992 to 53 in 2015. Besides, the average bank size of increased from Lebanese Pound 195.6 billion in 1992 to Lebanese Pound 5156.3 billion in 2015. Furthermore, a significant increase in concentration was recorded over that period, where the market share of the largest three banks increased from 22.7 percent in 1992 to 50 percent in 2015, and the market share of the largest five banks increased from 36.1 percent to 69.4 percent over the same period.

This increase in size of Lebanese banks was coupled with a large expansion of (local and foreign) branch networks, a the development of organisational structures and IT infrastructures, the introduction of a wider and more diversified banking products and services, and the gain of a larger base of clients. Furthermore, banks operating in Lebanon had undergone substantial technological changes that developed the way they provide services and the instruments used to provide them, such as the adoption of advanced electronic processing systems, the large spread of ATMs, and the internet banking. All that may have allowed Lebanese banks to realise economies of scale and scope, which usually result from expanding customers' base, offering wider range of products and services, and the cross-production of products and services. Scope efficiency gains may have been also created by sharing distribution systems and cost complementarities.

This study aims at detecting the impact of bank consolidation, restructuring, and modernisation on the economies of scale and scope of Lebanese banks, through a translogarithmic Fourier flexible cost function, with a main objective of determining the impact of size and diversification on the costs of those banks. Our empirical results 
do confirm the existence of economies of scale and scope resulting from appropriate exploitation of production factors (inputs) and suitable mix of products (outputs).

This paper proceeds as follows. In Section 2 we shed light on the relevant literature. The empirical methodology and the used variables are illustrated in Section 3. The empirical results and their interpretation are presented in Section 4. Finally, the conclusions of the study are presented in Section 5.

\section{Literature Review: Scale and Scope Economies in Banks}

The first research on economies of scale and scope in banks have been performed by Benston (1965) and Bell and Murphy (1968) who used a Cobb-Douglas single-product cost function, where banking production is identified by the number of credit and deposit accounts held by banks. The majority of studies performed before 1980s and using this methodology revealed the existence of economies of scale in the banking sector. In this regard, Benston (1965) tested the presence of economies of scale in the US commercial banks and obtained scale coefficients ranging between 0.877 and 0.967 according to the selected output, whereas Bell and Murphy (1968) obtained scale coefficients that vary from 0.896 to 0.975 .

In their study on the credit unions operating in British Columbia between 1976 and 1977, Murray and White (1983) found that most of the firms experience significant increasing returns-to-scale. Some other studied break down their analysis to a finer level, like Berger, Hanweck and Humphrey (1987) who found economies of scale for total deposits of less than $\$ 75$ million for the branch banking states, and diseconomies of scale for total deposits greater than $\$ 200$ million for the unit banking states. These authors also found very slight economies of scope between deposits and loans for banks with assets less than $\$ 50$ million and severe diseconomies of scope for those above $\$ 100$ million. Berger and Mester (1997) revealed the presence of economies of scale for banks with assets between $\$ 10$ billion and \$25 billion. Mitchell and Onvural (1996) studied the economies of scale and scope in US commercial banks, using a cost function based on Fourier series. The authors obtained economies of scale of 3 percent for banks with assets between $\$ 1$ billion and $\$ 100$ billion.

In a study on European banks, Vennet (1994) found empirical results that depend on the applied methodology (production approach or intermediation approach). In the first case, the author observed significant diseconomies of scale for banks with assets above $\$ 3$ billion, and efficiency opportunities for banks whose size is less than $\$ 1$ billion. In the case of the intermediation approach, the optimal size was found to be in a wide range, from $\$ 3$ to $\$ 10$ billion. These results were also confirmed by Molyneux and Gardener (1997) who, by performing a study on European banks, concluded the existence of economies of scale and significant diversification among credit and financial market operations that tend to increase with the size of banks.

The presence of scale economies was also verified for Italian banks for the period from 1982 to 1989 by Simper (1999) who obtained scale coefficients of about 0.82 (for the period 1982-1983), 0.79 (1984-1985), 0.77 (1986-1987), 0.95 (1988-1989), and 0.75 (1982-1989).

McKillop, Glass and Ferguson (2002) used a composite cost function to analyse the optimal size and the efficiency of the five largest Japanese banks during the period 1979-1991. By adopting the intermediation approach (with three inputs and three outputs), the composite specification shows the existence of statistically significant economies of scale for all sampled banks. This result was contested by Batchelor, Drake and Simper (2000), who, using a Fourier functional form, show the existence of constant returns-to- scale for the entire Japanese banking sector during the period 1992-1998.

Ashton (1998) employed a one-way fixed effects model with a translog specification of productive technology to test scale and scope economies in a sample of twelve UK retail banks over the period 1985-1997. The author adopted the two models of bank production (production approach and intermediation approach) and observed an overall slight diseconomies of scale for the latter approach and substantial diseconomies of scale for the former approach. Both models indicated overall diseconomies of scale for banks with excess of $£ 5$ billion in total assets. The author stated that this finding implies that the continuing growth of the UK retail banks has been driven by factors other than cost and efficiency considerations.

Schure and Wagenvoort (1999) investigated the cost efficiency of 1974 credit institutions across 15 European countries over the five-year period following the implementation of the Second Banking Directive in 1993. The authors stated that no major economic gains from economies of scale were found for the overall European banking industry, and that significant scale effects were only found for small institutions (with total assets up to $€ 600$ million).

Allen and Liu (2005) measured the economies of scale and cost efficiency of Canada's six largest banks over the period 1983-2003, using flexible translog cost functions. The authors' results led them firstly to reject the 
existence of constant returns-to-scale, and depending on the used model and assumptions, they found that banks could reduce their average cost by 6 to 20 percent through doubling their output.

Wheelock and Wilson (2009) estimated the returns-to-scale for all US banks over the period 1984-2006. The authors' results indicated that as recently as 2006, most US banks faced increasing returns-to-scale, suggesting that scale economies were a plausible (but not necessarily the only) reason for the growth in average bank size.

Regarding economies of scope, Gilligan and Smirlock (1984) adopted an approach based on the production of two outputs (deposits and loans) on a sample of 2700 US banks over the period 1973-1978. The estimation results obtained by the authors proved the existence of cost complementarities between banking outputs for large banks. This result was also confirmed by Mester (1993) who found important and significant economies of scope between mortgages and security investments. LeCompte and Smith (1987) found economies of scope between consumer credit and mortgage loans. However, their results were less clear-cut regarding traditional banking activities (i.e. loans and deposits) and market activities. Conversely, Berger and Humphrey (1991) found diseconomies of scope between bank outputs ranging between 10 percent and 20 percent. In addition, Pulley and Humphrey (1993) found that large US banks did not record cost complementarities between deposits and loans.

\section{Methodology and Variables}

\subsection{Methodology}

Following the majority of recent studies, e.g. Murray and White (1983), Youn (1986), Mester (1987), Hardwick (1989), Kolari and Zardkoohi (1990), Humphrey (1990, 1993) and Rezvanian, Mehdian and Elyasiani (1996), we estimate a multiproduct translogarithmic cost function. The use of a flexible functional form is almost mandatory nowadays, since most of specific functional forms have been systematically rejected in the 1970s by many studies, e.g. Flannery (1974) and Koot (1978).

A major limitation of the Cobb-Douglas framework is that banks are assumed to produce one output with the same inputs and technology, and this assumption is debatable given that banks diversify their business lines. Moreover, the Cobb-Douglas framework also has an overly restrictive functional form. The superiority of the translog function over the Cobb-Douglas form is the fact that the separability is not postulated a priori, but in fact tested. In addition, the translog function does not constraint the partial elasticities of substitution proposed by Allen-Uzawa to be unitary or constant but rather allows them to vary between periods and with the mix of production and inputs.

Assuming that banks operating in Lebanon try to minimise their total costs, the specification of a multiproduct cost function is defined by a quadratic function of products and prices of production factors. The expansion of the Taylor series around the sample mean used for the estimation of the cost function is formulated as follows:

$$
\begin{aligned}
\operatorname{Ln}\left(\frac{C T}{w_{3}}\right)= & \alpha_{0}+\sum_{i=1}^{3} \alpha_{i} \operatorname{Lny}_{i t}+\frac{1}{2} \sum_{i=1}^{3} \sum_{k=1}^{3} \alpha_{i k} \operatorname{Lny}_{i t} \operatorname{Lny}_{k t}+\sum_{j=1}^{3} \beta_{j} \operatorname{Ln}\left(\frac{p_{j}}{p_{3}}\right) \\
& +\frac{1}{2} \sum_{j=1}^{3} \sum_{m=1}^{3} \psi_{j m} \operatorname{Ln}\left(\frac{p_{j t}}{p_{3}}\right) \operatorname{Ln}\left(\frac{p_{m t}}{p_{3}}\right)+\sum_{i=1}^{3} \sum_{j=1}^{3} \eta_{i j} \operatorname{Lny} y_{i t} \operatorname{Ln}\left(\frac{p_{j t}}{p_{3}}\right)+u_{i t}
\end{aligned}
$$

Where $C T$ is the total cost, $y_{i}, y_{k}$ represent the quantities produced of each output, $p_{i}, p_{j}$ represent the prices of production factors, and $\varepsilon_{i}$ a random error term.

For Equation (1) to be a cost function, it must be concave and homogeneous of degree 1 and that $\psi_{j m}=\psi_{m j}$. The homogeneity of degree 1 with respect to price is induced by the conditions $\beta_{j}=1, \sum_{j} \psi_{j m}=\sum_{i} \eta_{i j}=0$. We therefore ensure that this characteristic is imposed before estimating the cost function. Once the parameters of the cost function are estimated, the concavity characteristic will be verified if the matrix of coefficients $\psi_{j m}$ is semi-definite negative and if the cost elasticity with respect to prices of production factors is non-negative (the monotony characteristic). We will also test the expansion of the production technology in order to verify if the prices of production factors and the production levels are independent, i.e., if the parameters of the cross products of these variables are zero. Therefore, this necessitates imposing that the parameters corresponding to 
cross products between production factor prices and quantities produced are jointly equal to zero: $\eta_{i j}=0, \forall i$.

According to Shephard's Lemma, we can develop the expression (1) with respect to the prices of production factors as follows:

$$
S=\sum_{j} \frac{\partial \ln C}{\partial p_{j}}=\sum_{j}\left(\beta_{j}+\sum_{j} \psi_{j m} \cdot \ln p_{h}+\sum_{i} \eta_{i j} \cdot \ln y_{i}\right)
$$

\subsection{Economies of Scale, Economics of Scope, and Partial Elasticity of Substitution}

Boot (2003) stated that the possible sources of economies of scale and scope in banking are broadly divided in four groups: (1) economies of scale and scope related to information and communication technology, (2) economies of scale and scope arising through reputation and branding, (3) innovation-related economies of scale and scope, and (4) risk diversification. The analysis of the cost function of banks operating in Lebanon may lead us to identify the existence of scale and scope economies and the sources of these economies. In this regard, we distinguish three types of economies of scale and scope.

\subsubsection{Global Economies of Scale (GESA)}

The concept of economies of scale applied to a translogarithmic cost function is mostly based on the work of Panzar and Willig (1977) and Brown, Caves and Christensen (1979). Global economies of scale represent the cost economies resulting from a proportional increase of the set of products. Within the framework of the parameters of the translog cost function, this measure can be written as:

$$
G E S A=\sum_{i}\left(\alpha_{i}+\sum_{i} \eta_{i k} \operatorname{Lny}_{k}+\sum_{i} \theta_{j h} \operatorname{Lnp}_{j}\right)
$$

If $G E S A<1$, the costs increase proportionately less than the set of products, i.e., the banks benefit from global economies of scale. If $G E S A>1$, the banks demonstrate global diseconomies of scale because costs increase proportionately more than production. If $G E S A=1$, costs increase in the same proportions as production, i.e., the banks witness constant returns-to-scale.

\subsubsection{Economies of Scale Specific to a Product (ESSAY)}

While the measure of global economies of scale describes the evolution of costs when the production varies along a radius, the specific economies of scale take into account the multidimensional nature of these activities. They are concerned with the production of a specific output $i$ when it varies, while the other outputs remain constant. By substituting the estimated coefficients of the model, the expression becomes:

$$
\operatorname{ESSAY}_{i}=\frac{C(y, p)}{y_{i}^{2}}\left[\hat{\alpha}_{i i}+\frac{\partial \operatorname{LnC}(y, p)}{\operatorname{Lny}_{i}}\left(\frac{\partial \operatorname{LnC}(y, p)}{\operatorname{Lny}_{i}}-1\right)\right]
$$

If $E S S A Y_{i}<0$, the marginal cost of product $i$ is decreasing, which implies economies of scale specific to the product $i$. If $E S S A Y_{i}>0$, banks have diseconomies of scale specific to the product $i$.

\subsubsection{Economies of Scale Specific to a Production Factor (ESSAP)}

Because of the duality between the cost function and the production function, the degree of economies of scale is also measured by the elasticity of the quantity produced relative to the quantity of production factors. As underlined by Hardwick (1990), it is useful, in order to identify other sources of economies or diseconomies of scale, to measure the cost reduction attribuable to the $j$-th factor of production when the firm grows. The economies of scale specific to a production factor $\left(E E S A P_{j}\right)$ are then given by:

$$
\operatorname{ESSAP}_{j}=\sum \frac{\partial \operatorname{LnS} S_{i}}{\partial \operatorname{Lny}}+\sum \frac{\partial \operatorname{LnC}(y, p)}{\operatorname{Lny} y_{i}}
$$

If $\operatorname{ESSAP}_{j}>1$, banks demonstrate diseconomies of scale specific to the production factor $j$. If $\operatorname{ESSAP}_{j}<1$, the cost of using the factor $j$ decreases. If $E S S A P_{j}=1$, the costs increase in the same proportion as the production factor $j$.

\subsection{Global Economies of Scope (GESP)}

The global economies of scope indicate the existence of complementarities among the various products offered by banks. The GESP are defined in a multi-product context, with the following expression (Clark, 1988): 


$$
G E S P=\left(\frac{C\left(y_{1}, 0, \ldots\right)+C\left(0, y_{2}, 0, \ldots\right)+\ldots+C\left(0,0, \ldots y_{i}\right)}{C\left(y_{1}, y_{2}, \ldots\right)}\right)-1
$$

If $G E S P>0$, it is more feasible - in terms of cost - for one bank to diversify into the production of the product $i$, then many banks specialise in the production of this product $i$. in this case, the bank records global economies of scope. If $G E S P<0$, global diseconomies of scope are present.

\subsubsection{Economies of Scope Specific to a Product (ESSCY)}

The economies of scope specific to a product seek to verify the impact of separating the product $i$ from the scope of products. Thus, if it is more feasible in terms of costs to exclude the product $i$ from the scope of products, the product $i$ does not then present economies of scope specific to a product. The mathematical expression of this measure is given as follows (Clark, 1988):

$$
\operatorname{ESSCY}_{i}=\left(\frac{C\left(y_{1}, 0,0, \ldots, 0\right)+C\left(0, y_{2}, y_{3}, \ldots\right)}{C\left(y_{1}, y_{2}, y_{3}, \ldots\right)}\right)-1
$$

If $E S S C Y_{i}>0$, economies of scope specific to product $i$ exist, i.e., it is feasible for banks to include the product $i$ in the diversification process. If $\operatorname{ESSCY}_{i}<0$, the product $i$ represents diseconomies of scope and therefore, it is more feasible - in terms of costs - to exclude the product $i$ from the scope of products.

\subsubsection{Cost Complementarities (CC)}

Beside the economies of scale, banks can benefit from cost savings through the joint production of several outputs (LeCompte \& Smith, 1990; Gilliang \& Simrlock, 1984). These economies of complementarity depend on the presence of complementary of costs between different outputs. Complementarity of costs implies that the marginal cost of an output decreases, or at least does not increase, when the quantity produced of the other output is increased (Baumol, Panzar, \& Willig, 1982). Cost complementarities are calculated in the framework of the translog specification, as follows:

$$
\begin{aligned}
C C_{i k} & =\frac{\partial^{2} \ln C T}{\partial y_{i} y_{k}}=\frac{\partial^{2} \ln C T}{\partial \ln y_{i} \partial \ln y_{k}}+\left(\frac{\partial \ln C T}{\partial \ln y_{i}} \cdot \frac{\partial \ln C T}{\partial \ln y_{k}}\right)<0 \\
& =\mu_{i k}+\left(\alpha_{i}+\sum_{l} \eta_{i k} \operatorname{Ln} Y_{k}+\sum_{j} \sigma_{i j} L n P_{j}\right)\left(\alpha_{k}+\sum_{l} \eta_{k i} L n Y_{i}+\sum_{j} \sigma_{i j} L n P_{j}\right)
\end{aligned}
$$

In practice, we calculate the economies of complementarity through the average point $(y=1, p=1)$, which greatly simplifies the formula of $C C_{i k}$ that becomes:

$$
C C_{i k}=\eta_{i k}+\alpha_{i} \alpha_{k}<0
$$

Under this formula, economies of diversification exist when $C C_{i k}<0$.

\subsection{Partial Elasticity of Substitution (PES)}

The partial elasticity of substitution between the production factors $j$ and $h$ measure the effect of a change in the price of production factor $h$ on the conditional demand for production factor $j$. This measure is obtained by evaluating the following expression:

$$
P E S_{j h}=\frac{\left\{\frac{\partial^{2} \operatorname{Ln}(y, p)}{\partial \operatorname{Ln} p_{j} \operatorname{Lnp} p_{h}}+\left(\frac{\partial \operatorname{LnC}(y, p)}{\partial \operatorname{Ln} p_{j}}\right)\left(\frac{\partial \operatorname{LnC}(y, p)}{\partial \operatorname{Ln} p_{h}}\right)\right.}{\left(\frac{\partial \operatorname{LnC}(y, p)}{\partial \operatorname{Ln} p_{j}}\right)\left(\frac{\partial \operatorname{LnC}(y, p)}{\partial \operatorname{Ln} p_{h}}\right)}
$$

By substituting the expression of $\left(\frac{\partial \operatorname{Ln} C(y, p)}{\partial L n p_{j}}\right)$, which corresponds to the price elasticity $h$ relative to the total cost and knowing that $\left(\frac{\partial^{2} L n C(y, p)}{\partial L n p_{h}^{2}}\right)=\widehat{\theta}_{j h}$, the partial elasticity of substitution may then be rewritten as:

$$
P E S_{j h}=\frac{\left\{\theta_{j h}+\widehat{S}_{j} \widehat{S}_{h}\right\}}{\widehat{S}_{j} \widehat{S}_{h}}
$$


If $P E S_{j h} \geq 0$, then an increase in the price of factor $j$ has an effect of increasing the demand for factor $h$. The factors $j$ and $h$ are then substitutes. If $P E S_{j h} \leq 0$, the factors $j$ and $h$ are complementary factors.

\subsection{Variables Specifications and Data}

Two main approaches can be used to model the banking costs. Firstly, the intermediation approach, which states that the bank buys funds to produce interest-bearing assets. Since deposits involve an expense, they are considered as an input, so the banking costs are the sum of operating costs and interest expenses. The alternative approach - the production approach - considers the bank as a producer of both financial assets and deposit services. The latter are part of the banking products, so the costs are limited only to operating expenses related to personnel, capital, and other inputs. Humphrey (1990) argues that the production approach tends to overestimate the economies of scale. For instance, large US banks often have better credit ratings, which allow them to borrow at lower rates than smaller ones. This encourages the former to finance a major part of their asset with borrowed funds, and consequently, the ratio of operating costs to total costs is a negative function of bank size. McAllister and McManus (1993) also state that the traditional way of choosing input prices may bring about the economies of scale puzzle since larger firms have better risk diversification opportunities and thus lower cost of funding than small firms. Thus, considering operational costs only, leads to conclude the presence of economies of scale, when there could be actually a substitution between two inputs whose relative price changes with the bank's size. Nevertheless, the intermediation approach has also certain weaknesses. Banks make intense marketing efforts to attract deposits from the public, which clearly classify them as a product of banking activity. Moreover, by excluding deposits from banking products, one cannot perform a very interesting test of economies of scope, which is the complementarity of costs between deposit activities and credit activities. This dilemma has prompted many authors (e.g. Nathan \& Neave, 1989), to adopt a hybrid approach that consider deposits and loans as outputs without excluding financing costs from production costs.

Table 1. Descriptive statistics of variables

\begin{tabular}{|c|c|c|c|}
\hline & & 2000 & 2013 \\
\hline \multirow[t]{3}{*}{ Total Assets } & Mean & 2797.5 & 6795.3 \\
\hline & SD & 4085.2 & 10297.8 \\
\hline & $\mathrm{CV}$ & 1.46 & 1.52 \\
\hline \multirow[t]{3}{*}{ Total Earning Assets } & Mean & 2668.4 & 6476.4 \\
\hline & $\mathrm{SD}$ & 4001.2 & 9922.8 \\
\hline & $\mathrm{CV}$ & 1.49 & 1.53 \\
\hline \multirow[t]{3}{*}{ Loans and advances } & Mean & 551.1 & 1962.9 \\
\hline & SD & 759.7 & 2946.9 \\
\hline & $\mathrm{CV}$ & 1.38 & 1.50 \\
\hline \multirow[t]{3}{*}{ Other Earning Assets } & Mean & 2117.3 & 4513.5 \\
\hline & SD & 3241.5 & 6975.9 \\
\hline & $\mathrm{CV}$ & 1.53 & 1.55 \\
\hline \multirow[t]{3}{*}{ Off-Balance Sheet } & Mean & 505.5 & 1890.7 \\
\hline & $\mathrm{SD}$ & 1383.1 & 4820.5 \\
\hline & $\mathrm{CV}$ & 2.74 & 2.55 \\
\hline \multirow[t]{3}{*}{ Customer Deposits } & Mean & 2271.0 & 5637.0 \\
\hline & SD & 3359.3 & 8737.0 \\
\hline & $\mathrm{CV}$ & 1.48 & 1.55 \\
\hline \multirow[t]{3}{*}{ Fixed assets } & Mean & 71.9 & 82.6 \\
\hline & $\mathrm{SD}$ & 117.4 & 124.8 \\
\hline & $\mathrm{CV}$ & 1.63 & 1.51 \\
\hline \multirow[t]{3}{*}{ Number of employees } & Mean & 407 & 794 \\
\hline & $\mathrm{SD}$ & 446 & 1119 \\
\hline & $\mathrm{CV}$ & 1.10 & 1.41 \\
\hline \multirow[t]{3}{*}{ Interest and similar charge } & Mean & 107.3 & 213.5 \\
\hline & SD & 154.9 & 320.8 \\
\hline & $\mathrm{CV}$ & 1.44 & 1.50 \\
\hline \multirow[t]{3}{*}{ Staff expenses } & Mean & 20.4 & 53.0 \\
\hline & SD & 27.8 & 83.1 \\
\hline & $\mathrm{CV}$ & 1.37 & 1.57 \\
\hline
\end{tabular}




\begin{tabular}{lccc}
\hline Other operating expenses & Mean & 14.4 & 35.5 \\
& $\mathrm{SD}$ & 18.6 & 54.2 \\
& $\mathrm{CV}$ & 1.30 & 1.53 \\
\hline
\end{tabular}

Sources: BilanBanques. Notes: the figures are expressed in billions of Lebanese pound, except the number of employees. The exchange rate in both years was Lebanese Pound 1500/\$.

The estimation of economies of scale and scope of banks operating in Lebanon will be evaluated in two specifications in order to judge the stability of results. The first used specification (Model 1) contains three banking outputs: (1) total earning assets (TEA), (2) deposit activities (DEP), and (3) off-balance sheet activities (OBS). The second specification (Model 2) contains four outputs: (1) credit activities (CRE), (2) other earning assets (OEA), (3) deposits (DEP), and (4) off-balance sheet activities (OBS).

These activities use three factors of production: (1) financing cost, which is equal to interest expense divided by deposits, (2) the cost of physical capital, which is equal to general operating expenses divided by the number of branches, and (3) labour cost, which is equal to personnel expenses divided by the number of employees. Finally, the dependent variable is the total cost that includes all financial and operating expenses.

The exploited sample is a balanced panel data set that includes 37 banks, covering the period 2000-2013. Only commercial banks were included in the sample in order to have a homogeneous sample.

\section{Empirical Results}

\subsection{Economies of Scale and Scope}

The translog cost function is estimated by the maximum likelihood method to calculate the economies of scale, the economies of scope, and the elasticity of substitution. The results obtained are presented in Table 2.

Table 2. Estimation of the translog cost function

\begin{tabular}{|c|c|c|c|c|}
\hline & \multicolumn{2}{|c|}{ Model 1} & \multicolumn{2}{|c|}{ Model 2} \\
\hline & Coefficient & T-student & Coefficient & T-student \\
\hline$C$ & 0.0825 & 0.1043 & $-2.9602^{*}$ & -2.4175 \\
\hline $\ln y_{1}$ & -0.1758 & -0.3423 & $0.8028^{*}$ & 4.9683 \\
\hline $\ln y_{2}$ & $0.9442 *$ & 1.9987 & -0.0118 & -0.3688 \\
\hline $\ln y_{3}$ & $0.1732 *$ & 2.4233 & $0.3975^{*}$ & 2.4964 \\
\hline $\ln y_{4}$ & - & - & $0.1587 *$ & 2.2486 \\
\hline $\ln y_{1} \ln y_{1}$ & 0.0941 & 0.7669 & $0.0989 *$ & 3.7021 \\
\hline $\ln y_{1} \ln y_{2}$ & -0.1432 & -1.4098 & -0.0251 & -0.6629 \\
\hline $\ln y_{1} \ln y_{3}$ & $-0.0461^{*}$ & -1.9810 & -0.0630 & -1.3088 \\
\hline $\ln y_{1} \ln y_{4}$ & - & - & $-0.0361^{*}$ & -3.0042 \\
\hline $\ln y_{2} \ln y_{2}$ & $0.2005^{*}$ & 2.1834 & -0.0391 & -0.4640 \\
\hline $\ln y_{2} \ln y_{3}$ & $0.0443^{*}$ & 2.2072 & 0.0660 & 0.9422 \\
\hline $\ln y_{2} \ln y_{4}$ & - & - & -0.0229 & -1.0381 \\
\hline $\ln y_{3} \ln y_{3}$ & 0.0031 & 0.4398 & 0.0019 & 0.0213 \\
\hline $\ln y_{3} \ln y_{4}$ & - & - & 0.0309 & 1.2049 \\
\hline $\ln y_{4} \ln y_{4}$ & - & - & $0.0296^{*}$ & 3.8631 \\
\hline $\ln p_{1}$ & $-0.1721^{*}$ & -3.2816 & $0.0616^{*}$ & 3.8812 \\
\hline $\ln p_{2}$ & $0.0848^{*}$ & 1.9973 & -0.0172 & -0.9321 \\
\hline $\ln p_{1} \ln p_{1}$ & $0.1569^{*}$ & 3.3330 & -0.0387 & -0.9026 \\
\hline $\ln p_{1} \ln p_{2}$ & $-0.0786^{*}$ & -2.0441 & -0.0072 & -0.1497 \\
\hline $\ln p_{2} \ln p_{2}$ & $0.0245^{*}$ & 3.4513 & -0.0132 & -0.2659 \\
\hline $\ln y_{1} \ln p_{1}$ & -0.0047 & -0.6591 & 0.0183 & 0.3100 \\
\hline
\end{tabular}




\begin{tabular}{lcccc}
\hline $\ln y_{1} \ln p_{2}$ & $0.7737^{*}$ & 6.8505 & $0.0203^{*}$ & 2.4805 \\
$\ln y_{2} \ln p_{1}$ & -0.0199 & -0.2262 & -0.0029 & -0.3986 \\
$\ln y_{2} \ln p_{2}$ & $0.0481^{*}$ & 2.9375 & $0.5126^{*}$ & 5.6903 \\
$\ln y_{3} \ln p_{1}$ & $-0.0127^{*}$ & -9.9376 & 0.1122 & 1.5249 \\
$\ln y_{3} \ln p_{2}$ & -0.0036 & -0.2585 & $0.0610^{*}$ & 4.2185 \\
$\ln y_{4} \ln p_{1}$ & - & - & $-0.0121^{*}$ & -8.2432 \\
$\ln y_{4} \ln p_{2}$ & - & - & -0.0050 & -0.3486 \\
$R^{2}$ & 0.98 & - & 0.97 & \\
\hline
\end{tabular}

Note. $*$ denotes significantly different from zero at the $5 \%$ level.

The results in Table 2 suggest that the translog form shows in both specifications, the existence of a significant linear relationship between the dependent variable (total cost) and the other selected variables. The partial effects of credit and deposit activities have also positive impacts on the total cost. The highest effects are generally attributable to deposits and off-balance sheet activity in the first specification, while credit, deposit, and off-balance sheet activities have greater influence on the total cost of banks operating in Lebanon, in the second specification.

The coefficients of the interaction among the outputs, measuring the joint effect of the explanatory variables on total cost, and the coefficients of interaction among factor prices have a negative sign, while the coefficients of interaction between the same outputs and between the same input prices have a positive sign, which is in line with economies of scope. Therefore, both specifications lead to suggesting the presence of economies of scale and scope in the Lebanese banking, in general.

\subsection{Global Economies of Scale, Economies of Scale Specific to a Product, and Economies of Scale Specific to a Production Factor}

The results of Table 3 (Panel A) shows that the coefficients of global economies of scale are statistically less than unity. Thus, banks operating in Lebanon demonstrate average global scale economies of about 4.2 percent, which are significantly less than unity at the 1 percent level for the first specification. The second specification suggests even stronger economies of scale, with cost savings of about 10.5 percent (i.e. a long-term reduction in the average cost of 10.5 percent), which are significantly less than unity.

Therefore, we can reject the hypothesis of constant returns-to-scale and conclude the presence of economies of scale, which implies a significant cost advantage for larger banks. For example, if banking output increases from a value of 100 to 200, the total production cost would increase from a value of 100 to 195.8 (in the first specification) and to 189.5 (in the second specification). Therefore, doubling the size of assets allows a reduction in the unit cost by about 4.2 percent and 10.5 percent as shown in Table 3 .

Regarding economies of scale specific to a product (Table 3, Panel B), their presence indicate those outputs for which banks would benefit from increasing their operations. Conversely, banks should reduce their activities in areas where there are diseconomies of scale specific to a product. Economies of scale specific to products show that the activities that allow the largest reductions in long-term average costs are the off-balance sheet activities (according to the first specification), which are statistically significant at the 5 percent level. With regard to the second specification, deposits, other earning assets, and off-balance activities are the elements of bank outputs that result in long-term cost savings, i.e. which involve marginal cost reduction.

Economies of scale specific to production factors help identifying the factors that contribute the most in reducing long-term costs of banks operating in Lebanon. The results shown in Table 3 (Panel C) show that the three coefficients are statistically different from zero at the 1 percent level. In fact, a more efficient use of labour and, to a lesser extent, capital (especially in the second specification) can contribute in reducing long-term costs of banks operating in Lebanon. Since bank physical capital includes office equipment and electronic processing systems, we may witness here a measure of gains related to the computerisation of the operations performed by banks. Conversely, a more intensive use of financial capital tends to reduce economies of scale. In this regard, an increase in deposit activities involves higher costs, which do not allow the reduction of costs. 
Table 3. Estimations of global and specific economies of scale

\begin{tabular}{|c|c|c|c|}
\hline & & Model 1 & Model 2 \\
\hline \multicolumn{4}{|c|}{ Panel A: Global economies of scale $(\overline{G E S A})$} \\
\hline & & $0.9581 *$ & $0.8949 *$ \\
\hline \multicolumn{4}{|c|}{ Panel B: Economies of scale specific to a product (ESSAY) } \\
\hline$T E R$ & & $2.47 \mathrm{E}-10$ & \\
\hline$D E P$ & & $8.16 \mathrm{E}-09 \dagger$ & \\
\hline$O B S$ & & $-6.12 \mathrm{E}-07 \pm$ & \\
\hline & $C R E$ & & $7.35 \mathrm{E}-07 \pm$ \\
\hline & $O E A$ & & $-2.83 \mathrm{E}-09$ \\
\hline & $D E P$ & & $-1.05 \mathrm{E}-08$ \\
\hline & $O B S$ & & $1.16 \mathrm{E}-06 \pm$ \\
\hline \multicolumn{4}{|c|}{ Panel C: Economies of scale specific to a production factor (ESSAP) } \\
\hline Financial Capital & & $0.9678 *$ & $0.9308 *$ \\
\hline Physical Capital & & $0.9632 *$ & $0.8907 *$ \\
\hline Labour & & $0.9432 *$ & $0.8630 *$ \\
\hline
\end{tabular}

Notes. $*$ denotes rejecting $H_{0}: G E S A=1$ and $E S S A Y=1$ at $1 \%$ confidence level. $\dagger$ and \pm denotes rejecting $H_{0}: E S S A P=0$ at the $1 \%$ and $5 \%$ confidence levels respectively.

\subsection{Global Economies of Scope, Economies of Scope Specific to a Product and Cost Complementarities (or} Sub-Additivity of Costs)

The presence of economies of diversification is difficult to demonstrate empirically, since it requires the estimation of a cost function by giving zero values for certain outputs. This approach has a weakness because the logarithmic specification of the translog function cannot handle zero values and we must replace these values with low positive values, chosen arbitrarily.

Table 4. Estimations of economies of scope under different hypotheses of replacement of the null production (the first specification)

\begin{tabular}{|c|c|c|c|c|}
\hline & Minimum value & $1 \%$ & $5 \%$ & $10 \%$ \\
\hline \multicolumn{5}{|c|}{ Panel A: Global economies of scope (GESP) } \\
\hline & $0.8632 *$ & $0.6370 *$ & $0.6391 *$ & $0.6447 *$ \\
\hline \multicolumn{5}{|c|}{ Panel B: Specific economies of scope (ESSCY) } \\
\hline$T E R$ & $0.6902 \dagger$ & $0.7624 \dagger$ & $0.7606 \dagger$ & $0.7578 \dagger$ \\
\hline$D E P$ & $0.6961 \dagger$ & $0.5279 \dagger$ & $0.5425 \dagger$ & $0.5613 \dagger$ \\
\hline$O B S$ & $0.2586 \dagger$ & $-0.0128 \dagger$ & $-0.0089 \dagger$ & $-0.0011 \dagger$ \\
\hline Panel C: Cost complementarity $(C C)$ & Average value & & & \\
\hline$C C y_{1} y_{2}$ & $-0.1702 \pm$ & & & \\
\hline$C C y_{1} y_{3}$ & $-0.0328 * *$ & & & \\
\hline$C C y_{2} y_{3}$ & $0.0518 \pm$ & & & \\
\hline
\end{tabular}

The problem with the cost estimation when the quantity produced of certain outputs is null was overcome by replacing the zero values with different values. In this regard, Kolari and Zordkoohi (1990) and Rezvanian, Mehdian and Elyasiani (1996) used the minimum value of the sample instead. But as by pointed by Pulley and Humphery (1993), this approach could also lead to very different results for economies of scope, depending on whether the substituted positive value is close to zero or not. In response to the concerns of Pulley and Humphery (1993), we test the sensitivity of our results using four different replacement values: the minimum value of the sample, and 1 percent, 5 percent, and 10 percent of the sample average. 
Table 5. Estimations of economies of scope under different hypotheses of replacement of the null production (the second specification)

\begin{tabular}{|c|c|c|c|c|}
\hline & Minimum value & $1 \%$ & $5 \%$ & $10 \%$ \\
\hline \multicolumn{5}{|c|}{ Panel A: Global economies of scope $(G E S P)$} \\
\hline & $1.4679 *$ & $0.5079 *$ & $0.5902 *$ & $0.6955 *$ \\
\hline \multicolumn{5}{|c|}{ Panel B: Specific economies of scope (ESSCY) } \\
\hline$C R E$ & 0.8243 & $0.5934 \dagger$ & $0.6198 \dagger$ & $0.6516 \dagger$ \\
\hline$O E A$ & $0.5407 \dagger$ & $0.1700 \dagger$ & $0.1974 \dagger$ & $0.2325 \dagger$ \\
\hline$D E P$ & $0.3477 \dagger$ & $-0.0975 \dagger$ & $0.1251 \dagger$ & $0.1607 \dagger$ \\
\hline$O B S$ & $0.5031 \dagger$ & $0.1414^{\top}$ & $0.1689 \dagger$ & $0.2043 \dagger$ \\
\hline Panel C: Cost complementarity $(C C)$ & Average value & & & \\
\hline$C C y_{1} y_{2}$ & $-0.0086 * *$ & & & \\
\hline$C C y_{1} y_{3}$ & $-0.0298 \pm$ & & & \\
\hline$C C y_{1} y_{4}$ & $-0.0349 \pm$ & & & \\
\hline$C C y_{2} y_{3}$ & $0.0119 \pm$ & & & \\
\hline$C C y_{2} y_{4}$ & 0.00003 & & & \\
\hline$C C y_{3} y_{4}$ & $0.0578 \pm$ & & & \\
\hline
\end{tabular}

Tables 4 and 5 present the empirical results for various replacement strategies of the null output. Lebanese banks show advantages in terms of cost in providing multiple outputs simultaneously. Since the coefficients of cross outputs are positive, the coefficients of scope economies are positive and significant indicating the presence of global scope economies. This result is verified regardless of the replacement strategy used. When we use the minimum value of the sample, the coefficient value of global economies of scope ranges from 0.86 to 0.64 (in the first specification) and 1.46 to 0.50 (in the second), which implies a weak sensitivity of the results to the choice of the replacement value of null production in the first specification, but strong sensitivity in the second specification. While the replacement value is maintained within the indicated limits, the coefficient of GESP does not vary considerably. We note here that even when we use a replacement value of 50 percent of the sample average, the coefficient of global economies of scope remains very close to those already obtained in the first and second specifications.

This result shows that the translogarithmic cost function captures correctly the production technology of Lebanese banks especially when it is represented by the first specification, and that the concerns of Pulley and Humphrey (1993) should be taken into consideration. However, it should be noted that the sensitivity of our results is not of a great concern, because the different values of the coefficient of scope economies are positive and highly significant, thus advocate the presence of global economies of scope.

With regard to ESSCY, the two specifications estimate economies of scope specific almost for all products. The results of the different tests of economies of scope specific to products show that total earning assets, deposit activities (in the first specification - Table 4) and credit activities (in the second specification - Table 5) produce the largest economies of scope with coefficients of 69 percent, 69.6 percent and 82.4 percent respectively. Note that the coefficients of economies of scope are positive, thus supporting the presence of significant economies of scope, except for credits.

As for cost complementary, the indicator of economies of diversification is negative and statistically significant, though at low magnitude, suggesting that banks benefit from the subadditivity of costs. We cannot reject the hypothesis that banks could slightly reduce their costs by specialising in the simultaneous production of certain outputs.

\subsection{Partial Elasticity of Substitution}

The theoretical development of the banking cost function shows a substitutability among bank inputs. Each of these factors is positively inter-connected to the volume of intermediation. The services of financial intermediation cannot be generalised and the collection of banking resources do not increase as a result of an increase in bank production factors. Table 6 shows our measures of the partial elasticities of substitution among the factors of production. 
Table 6. Estimations of the partial elasticities of substitution among production factors (first and second specifications)

\begin{tabular}{lcc}
\hline & Model 1 & Model 2 \\
\hline Financial Capital, Physical Capital & 0.1235 & 0.1053 \\
Financial Capital, Labour & $0.7071 *$ & $0.4593 *$ \\
Physical Capital, Labour & $1.1925 \dagger$ & $1.0579 \dagger$ \\
\hline
\end{tabular}

Notes. $\uparrow$ and $*$ denote rejecting $P E S_{i}=0$ at the confidence levels $1 \%$ and $5 \%$ respectively.

The empirical results show high level of substitutability between labour and physical capital, as demonstrated by the measure of partial elasticities of substitution, which ranges between 1.19 (in the first specification) and 1.06 (in the second). Thus, an increase in the price of physical capital by 1 percent increases the ratio between capital and labour by 1.19 percent and 1.06 percent respectively. Conversely, we notice a lack of substitutability between physical capital and financial capital, and between labour and financial capital.

\section{Conclusion}

The Lebanese banking sector witnessed substantial decline in the number of operating commercial banks coupled with a large increase in the size of those banks. This fact may have allowed Lebanese banks to achieve economies of scale and scope, resulting from expanding their customers' base, offering wider range of financial services, and the cross-production of banking products.

This study aimed at estimating the economies of scale and scope in the Lebanese banking sector by adopting a translogarithmic cost function. Using a sample of 37 commercial banks over the period 2000-2013, our empirical results suggest the presence of economies of scale, with cost elasticity related to production factors of about 5 percent. These savings are primarily related to efficiency gains in the use of labour and physical capital as evidenced by the economies of scale specific to production factors. The global economies of scope are also present and highly significant, and the adopted explanatory variables result in statistically significant cost savings. In addition, our results show a significant cross-product complementarity. This simultaneous presence of economies of scale and scope may explain the trend towards consolidation observed in the Lebanese banking sector. Finally, our results show that the technology adopted by banks operating in Lebanon is characterised by substitutability between physical capital and labour.

\section{References}

Awdeh, A., \& EL-Moussawi, C. (2011). Analysing the motives and the outcomes of bank mergers. Middle Eastern Finance and Economics, 15, 6-20.

Batchelor, D., Drake, L., \& Simper, R. (2000). Scale economies and technological change in Japanese banking: An application of an entry/exit model. Working Paper, Financial Services Authorities, London.

Baumol, W., Panzar, J., \& Willig, R. (1982). Contestable markets and the theory of industry structure. Harcourt Brace Jovanovich, San Diego, CA.

Bell, F., \& Murphy, B. (1968). Cost in commercial banking: A quantitative analysis of bank behavior and its relation to bank regulation. Research report to the Federal Reserve Bank of Boston, No. 41.

Benston, G. (1965). Branch banking and economies of scale. Journal of Finance, 20, 312-331. http://dx.doi.org/10.1111/j.1540-6261.1965.tb00212.x

Berger, A., \& Humphrey, D. (1991). The dominance of inefficiencies over scale and product mix economies in banking. Journal of Monetary Economics, 28, 117-148. http://dx.doi.org/10.1016/0304-3932(91)90027-L

Berger, A., \& Mester, L. (1997). Inside the black box: What explains differences in the efficiencies of financial $\begin{array}{lllll}\text { institutions? Journal of Banking and } & \text { Finance, }\end{array}$ http://dx.doi.org/10.1016/S0378-4266(97)00010-1

Berger, A., Hanweck, G., \& Humphrey, D. (1987). Competitive viability in banking. Journal of Monetary Economics, 20, 501-520. http://dx.doi.org/10.1016/0304-3932(87)90039-0

BilanBanques, Bank Data Financial Services, Lebanon.

Boot, A. (2003). Consolidation and Strategic Positioning in Banking with Implications for Europe. Brookings-Wharton Papers on Financial Services, 37-83. http://dx.doi.org/10.1353/pfs.2003.0001

Brown, S., Caves, D., \& Christensen, L. (1979). Modelling the structure of cost and production for multiproduct 
firms. Southern Economic Journal, 46, 256-273. http://dx.doi.org/10.2307/1057018

Clark, J. (1988). Economies of scale and scope at depository financial institutions: A review of the literature. Federal Reserve Bank of Kansas City Economic Review, September/October, 16-33.

Gilligan, T., \& Smirlock, M. (1984). An empirical study of the joint production and scale economies in $\begin{array}{llllll}\text { commercial banking. Journal of Banking and Finance, } & \text { 67-76. }\end{array}$ http://dx.doi.org/10.1016/S0378-4266(84)80025-4

Hardwick, P. (1989). Economies of scale in building societies. Applied Economies, 21, 1291-1304. http://dx.doi.org/10.1080/758522325

Humphrey, B. (1990). Why do estimates of bank scale economies differ? Federal Reserve Bank of Richmond Economic Review, 76, 38-50.

Humphrey, B. (1993). Cost and technical change: Effects from bank deregulation. The Journal of Productivity Analysis, 4, 9-34. http://dx.doi.org/10.1007/BF01073463.

Kolari, J., \& Zardkoohi, A. (1990). Economies of scale and scope in thrift institutions: The case of Finnish cooperative and saving banks. Scandinavian Journal of Economics, 92, 437-451. http://dx.doi.org/10.2307/3440010

Koot, S. (1979). On economies of scale in credit unions. Journal of Finance, 33, 1087-1094. http://dx.doi.org/10.1111/j.1540-6261.1978.tb02049.x

LeCompte, R., \& Smith, S. (1987). An empirical analysis of scale and scope economies in the savings and loan industry. Working Paper, Texas Christian University, Georgia Institute for Technology.

McAllister, P., \& McManus, D. (1993). Resolving the scale efficiency puzzle in banking. Journal of Banking and Finance, 17, 389-405. http://dx.doi.org/10.1016/0378-4266(93)90039-G.

Mester, L. (1987). A multiproduct cost study of saving and loans. Journal of Finance, 42, 423-445. http://dx.doi.org/10.1111/j.1540-6261.1987.tb02575.x

Mester, L. (1993). Efficiency in the savings and loan industry. Journal of Banking and Finance, 17, 267-286. http://dx.doi.org/10.1016/0378-4266(93)90032-9

Molyneux, P., \& Gardener, E. (1997). Cost economies in European banking and the implications of EMU. CEPS Business policy report, no. 4, 1-14.

Murray, D., \& White, W. (1983). Economies of scale and economies of scope in multiproduct financial institutions: A study of British Columbia credit unions. Journal of Finance, 3, 887-902. http://dx.doi.org/10.1111/j.1540-6261.1983.tb02508.x.

Nathan, A., \&Neave, E. (1989). Competition and contestability in Canada's financial system: Empirical results. Canadian Journal of Economics, 22, 576-594. http://dx.doi.org/10.2307/135541

Panzar, J., \& Willig, R. (1977). Economies of scale in multi-output production. The Quarterly Journal of Economics, 91, 481-493. http://dx.doi.org/10.2307/1885979

Pulley, L., \& Humphrey, D. (1993). The role of fixed costs and cost complementarities in determining scope economies and the cost of narrow banking proposals. The Journal of Business, 66, 437-462. http://dx.doi.org/10.1086/296611

Rezvanian, R., Mehdian, S., \& Elyasiani, E. (1996). Economies of scale and scope in small depository institutions: Evidence from U.S. cooperative banks. Quarterly Review of Economics and Finance, 36, 39-54. http://dx.doi.org/10.1016/S1062-9769(96)90028-9

Simper, R. (1999). Economies of scale in the Italian saving bank industry. Applied Financial Economic, 9, 11-19. http://dx.doi.org/10.1080/096031099332492

Vennet, V. (1994). Concentration, efficiency and entry barriers as determinants of E.C. bank profitability. Journal of International Financial Markets, Institutions, and Money, 4, 21-46.

Youn Kim, H. (1986). Economies of scale and economies of scope in multiproduct financial institutions: Further evidence from credit unions. Journal of Money, Credit and Banking, 18, 220-226. http://dx.doi.org/10.2307/1992205 


\section{Copyrights}

Copyright for this article is retained by the author(s), with first publication rights granted to the journal.

This is an open-access article distributed under the terms and conditions of the Creative Commons Attribution license (http://creativecommons.org/licenses/by/3.0/). 